compose the employer-employee relationship, Section 8(c), by placing blinders upon the Board, has hindered its effectiveness in translating the guarantee of uncoerced elections into reality. Regardless of whether the courts permit continued broad use of the Board's weaker sanction, the Taft-Hartley Act has done much to destroy the value of the NLRB's skill in accurately appraising employer speech.

\title{
SOVEREIGN IMMUNITY FOR COMMERCIAL INSTRUMENTALITIES OF FOREIGN GOVERNMENTS*
}

THE venerable doctrine of sovereign immunity affords an inviting sanctuary for foreign countries seeking to exempt their state trading organizations from liability in the courts of other nations. While no canon of international law dictates that any such exemption be proffered, ${ }^{1}$ sovereigns themselves have been accorded immunity since the early days when an insult to a king was a potential casus belli.2 The same considerations of comity and diplomatic expediency have influenced all nations to expand this originally personal privilege to "governmental" activities of foreign states. ${ }^{3}$ Most European nations go no further, denying immunity to "proprietary" activities."

dicator of the number of certification elections and hence of the opportunitics for interference with free choice, rose $2.5 \%$ in the New England states, $48.6 \%$ in the South Atlantic region, and $70 \%$ in the East South Central states. Id. The average increase in both unfair practice and representation cases for all Regional Offices in 1947 was $21.6 \%$. The increase in southern offices was much higher. E.g., Baltimore: up $50.5 \%$, Atlanta: up $60.2 \%$; New Orleans : up $76.2 \%$. Id. at 70 .

*Lorina v. The Rossia (file no. 18767). Complaint dismissed without opinion by District Court, Eastern District of New York on April 6, 1948.

1. The Exchange, 7 Cranch 116, 136 (1812). A sovereign has a right to immunity only before the courts of his own state. See Hobbes, Leviatinas c. 18 (Oakeshott cel. 1946); Austin, Jurisprudence 336 (5th ed. 1885); Weston, Actions Against the Property of Sovereigns, 32 HARv. L. REv. 266, 270 (1919).

2. Traditionally, sovereign immunity was extended only to (1) the person of a foreign sovereign or head of state; (2) the person of an ambassador or other public minister; and (3) a foreign army or warship. WheATON, INTERNATIONAL LAW 151-2 (5th ed., Phillipson, 1916); see The Exchange, 7 Cranch 116, 137-40 (1812). The personal aspect of immunity still persists. E.g., Mighell v. Sultan of Johore, [1894] 1 Q.B. 149 (breach of promise suit against Sultan dismissed).

3. See Friedmann, The Growth of State Control over the Individual, and its Effect upon the Rules of International State Responsibility, 19 BRiT. X. B. INT'L L. 118 (1938).

4. This limitation is enforced in the courts of Belgium, Italy, Switzerland, Roumania, Austria, Greece, Egypt and France. Allen, The Position of Foreign States iefone Natronal Courts 31 (1933).

France first utilized this standard to curtail immunity in Gostorg et U.R.S.S. c. Association France-Export, Cour d'Appel de Paris 1926, Dalloz, Recuell Heddonadaime 56 
But in the United States immunity, although not without restriction, is granted more freely. While usually denied to government enterprises organized in corporate form,, 5 it is accorded to other commercial instrumentalities such as trading ships even though these would come within the category of "proprietary" activities. This liberal grant, in which competing private enterprises cannot share, directly aids the instrumentalities of foreign states at the expense of injured citizens who are thus deprived of judicial recourse." In an era of increasing socialism abroad, re-examination of the present policy of the United States toward granting immunity may be in order.

The recent libel of the Russian ship Rossia by an injured passenger ${ }^{\pi}$ serves to illustrate that policy in operation. Upon the institution of suit, the Soviet Ambassador officially presented a claim of immunity to the State Department, ${ }^{8}$ asserting that the ship was owned by the Soviet Ministry of Marine Fleet. The State Department, basing its decision on criteria laid down in previous judicial opinions, "recognized and allowed" the claim." The court, basing its decision on the State Department's recognition, dismissed the suit without further inquiry. ${ }^{10}$

The Rossia case indicates, paradoxically, that responsibility for the immunity policy of the United States rests primarily with the State Department, while explanation of that policy must be found largely in judicial doctrine. With increasing regularity the State Department has assumed the burden of de-

(1927), apparently in order to render Russian trading organizations subject to liability.

It is still uncertain whether France would apply this rule to the instrumentalities of other countries. ALIEN, op. cit. supra, at 171-4.

Great Britain is one of the few European countries which have never adopted the restriction. E.g., The Parlement Belge, 5 P.D. 197 (1880); The Porto Alesandre, [1920] P. 30; The Cristina, [1938] A.C. 485. See Reisenfield, Sozercign Immunity for Forcign $V$ essels in Anglo-American Law, 25 MrNN. L. Rev. 1, 7 et seq. (1940). The Netherlands is another exception. AlLEN, op. cit. stpra, at 147.

5. See notes 24-6 infra.

6. See Gould Coupler Co. v. U.S.S.B.E.F.C., 261 Fed. 716, 718 (S.D.N.Y. 1919) : "The immunity of the sovereign may well become a serious injustice to the citizen, if it can be claimed in the multitude of cases arising from governmental activities which are increasing so fast."; Lord Mfaugham's opinion in The Cristina, [1938] A.C. 485 at 521 : "Is it consistent with sovereign dignity to acquire a tramp steamer and to compete with ordinary trading ships in the markets of the world? Doing so, is it consistent to set up the immunity of a sovereign if, owing to the want of skill of captain and crew, serious damage is caused to the ship of another country?"

7. Lorina v. The Rossia (file no. 18767). Complaint dismissed without opinion by District Court, Eastern District of New York on April 6, 1948.

8. This method is the accepted alternative to appearance in court by an oficial representative to claim immunity as a bar to judicial proceedings. Ex Parte Muir, 254 U.S. 522, 532 (1921).

9. In a press release on the Rossia case, the State Department stated that recognition of the claim was based on judicial "decisions dating back to 1926." N.Y. Times, April 10, 1948, p. 29, col. 3.

10. The libel portion of a companion case, Suhl v. MIV Rossia and the Amtorg Trading Corp. (file no. 18762), was also dismissed. See note 23 infro. 
termining the validity of claims for immunity and its "suggestions" are accepted without hesitation by the courts.11 Prior to World War II, it is true, the department usually preferred merely to forward the claim to the courts for decision. ${ }^{12}$ And even now, judges are occasionally required to decide a claim independently because it is first presented in the judicial proceeding ${ }^{10}$ or because the State Department may still transmit it to the court without recommendation. ${ }^{14}$ Nevertheless, the judiciary has never seriously questioned the paramount authority of the State Department in this field. ${ }^{\text {Is }}$

11. Ex parte Peru, 318 U.S. 578 (1943); see United States v. Lec, 106 U.S. 196, 209 (1882) ; Mexico v. Hoffman, 324 U.S. 30, 34 (1945). But cf. footnote 15 infra.

For a statement as to the general lack of competence of courts in cases affecting international relations, see Mr. Justice Black, concurring in Z. \& F. Assets Realization Corp. v. Hull, 311 U.S. 470, 490 (1941). Judicial abstention is considered particularly appropriate in cases involving sovereign immunity. See, e.g., The Maipo, $259 \mathrm{Fcd}$. 367, 368 (S.D.N.Y. 1919) : "[I]f we do not approve of [state trading] . . then we must say so through diplomatic channels and not through the judiciary. Otherwise the judiciary are really contributing to what might become, under conceivable circumstances, a casus belli."

This judicial deference to the State Department has been defended on the one hand as being an accommodation to "diplomatic necessity", Note, 50 YALE L. J. 1088, 1093 (1941), JafFe, Judictal Aspects of Foreign Relations 77-8 (1933), and attacked on the other as overextending the power of the State Department, Jessup, Has the Supreme Court Abdicated One of its Functions?, 40 AM. J. INT'L L. 168 (1946).

12. E.g., Lamont v. Travelers Ins. Co., 281 N.Y. 362, 24 N.E.2d 81 (1939); Hannes v. Kingdom of Roumania Monopolies Inst., 260 App. Div. 189, 20 N.Y.S.2d 825 (1st Dep't 1940), 50 Yale L. J. 1088 (1941); see Deák, The Plea of Sovereign Immunity and the N. Y. Coutrt of Appeals, 40 Cor. L. Rev. 453 (1940).

In 1921 the State Department asserted that it "has made it a practice to refrain from taking any action ... in private litigation even though such litigation may involve merchant vessels owned by [a] foreign government." Letter from Undersecretary of State to Portugese Minister, Nov. 23, 1921, quoted in 2 Hackworth, DiGest OF INTERNATIONAL LAw 438 (1941). It does not appear that the State Department actually notified a court - that it "recognized and allowed" a claim made in behalf of a commercial instrumentality until ex parte Peru, 318 U.S. 578 (1943). In 1931 a claim made for a Dominican ship was recognized, but evidently this recognition was never transmitted to the court. 2 HACKWORTH, op. cit. supra at 446 (The Arminda).

13. The government, at its discretion, may first present the claim in court through an official representative instead of submitting it to the State Department. Ex parte Muir, 254 U.S. 522, 532 (1921). Where the facts of the case were in dispute, the State Department refused even to forward the claim to the court, advising the foreign ambassador to appear in the suit and present it. 2 HACKwORTH, op. cit. supra note 12, at 449-50 (The Navemar, 1936) and at 455-6 (The San Ricardo, 1938).

14. See note 12 supra.

15. Only once has the court ignored a State Department defermination. In Berizzi Bros. v. The Pesaro, 271 U.S. 562 (1926), the Supreme Court recognized a claim which had been specifically denied. But the Supreme Court was never so cavalier where the State Department had granted immunity. And in Mexico v. Hoffman, 324 U.S. 30, 35 (1945), the Court indicated that a State Department suggestion would never again be rejected, regardless of whether it granted or denied the claim. Moreover, it asserted that determinations which the judiciary was forced to make would be based exclusivcly on grounds which the State Department had previously approved. The opinion of the court 
But because the State Department has asserted its reliance on judicial decisions, even if such reliance is not compelled, and because courts themselves must on occasion decide claims independently, these decisions continue to be the only explicit basis for the present United States immunity policy. Thus where a ship, such as the Rossia, is involved, the primary requirement for immunity is possession of the vessel by a foreign government. ${ }^{10}$ Until 1926, a showing that the ship was employed for a "public purpose" was also required.7 But in Berizzi Bros. v. The Pesaro ${ }^{18}$ the Supreme Court held that state efforts at economic advancement constituted as much of a public purpose as, for example, the maintainance of a naval force. ${ }^{19}$ This conclusion in effect places every government-controlled ship in public service regardless of the nature of its activity. ${ }^{20}$

That corporations owned by foreign governments have not been similarly favored $^{21}$ seems the result of applying a legal fiction rather than a realistic distinction. Although these agencies have escaped when courts have found them indistinguishable from the government itself,

disowned only the judicial independence asserted in the Berizzi case; the doctrine of immunity there enunciated still stands. See p. 179 infra.

16. The requirement is "actual possession by some act of physical dominion . . . or at least some recognition on the part of the ship's officers that they were controlling the vessel and crew in behalf of the government." The Navemar, 303 U.S. 68, 75-6 (1938). This must have occurred prior to the libelling of the ressel. The Katingo Hadjipaters, 40 F.Supp. 546 (S.D.N.Y. 1941), affd, 119 F.2d 1022 (2d Cir. 1941). The "possession" test has been criticized as being an insufficient criterion. See Mfr. Justice Franlifurter, concurring in Mexico v. Hoffman, 324 U.S. 30 at 39-10 (1945); Sanborn, The Immurily of Gozernment-Onined Merchant Vessels, 39 Axr. J. IrT't L. 794 (1945).

17. The criteria of "possession" and "public purpose" were first applicd to a foreign vessel in Long v. The Tampico, 16 Fed. 491, 496 (S.D.N.Y. 1883) (libel of Mlesiean ship). The basis for that decision had earlier been establishcd in cases involving federal or state-owned ships or cargoes, id. at 4945 , the area in which U.S. law as to governmental immunities was first developed. See Reisenfield, supra note 4, at 36.

18. 271 U.S. 562 (1926).

19. This conclusion had previously been reached in four lower federal court cases. The Pampa, 245 Fed. 137 (E.D.N.Y. 1917); The Xraipe, 252 Fcd. 627 (S.D.N.Y. 1918); The Maipo, 259 Fed. 367 (S.D.N.Y. 1919); The Carlo Poma, 259 Fod. 369 (2d Cir. 1919), rev'd on jurisdictional grounds, 255 U.S. 219 (1921). Contra: The Pesaro, 277 Fed. 473 (S.D.N.Y. 1921). All of these ships except the Pesaro were to carry a government cargo of supplies or munitions on the return voyage, although this possible ground for distinction was not considered in The Maipo, 252 Fed. 627. Despite these decisions the Supreme Court had continued to insist that immunity for ships engaged in trade was an open question. See, c.g., Ex farte: In the Matter of the State of New York, 256 U.S. 503 (1921).

20. As a result, courts may ignore the "public purpose" requirement completely. E.g., Ervin v. Quintanilla, 99 F.2d 935 (5th Cir. 1938). But at times they still pay lip service to it. See The Navemar, 303 U.S. 68, 74 (1938).

21. The law concerning these entities, as with ships (see note 17 suspra), is derived primarily from cases involving instrumentalities of the United States. See cases cited in United States v. Deutches Kalisyndikat Gesellschaft, 31 F.2d 199, 202 (S.D.N.Y. 1929).

22. On this ground courts have granted immunity to railruad corporations. Dexter 
posed by one of three rationales, all of which treat the corporations as a separate entity not entitled to the protection accorded to a foreign state. ${ }^{33}$ Most frequently courts have reiterated the logic of Chief Justice Marshall that "when a government becomes a partner in any trading company, it divests itself, so far as concerns the transactions of that company, of its sovereign character, and takes that of a private citizen." 24 On other occasions, courts have held that by using the corporate device the state has chosen an instrumentality which can sue and be sued as a separate entity. ${ }^{25} A$ third rationale may be that since the suit is nominally against the corporation rather than the government, it is not proper to "pierce the corporate veil" to determine whether the stock is in fact owned by the state. ${ }^{20}$

While this fiction-formed policy as to corporations does reduce the number of instances in which suit by an injured party is barred, a more inclusive restriction which would also deny immunity in cases like The Rossia seems desirable in order to protect private interests more adequately. One method of achieving that result is the prevalent European practice of limiting the privilege to activities which are governmental rather than proprietary. ${ }^{27}$ This traditional distinction however, has proven far too uncertain even as a

\& Carpenter v. Kunglig Jarnvagsstyrelsen, 43 F.2d 705 (2d Cir. 1930) (since the corporation and "the government of Sweden are one and the same," inmunity should be granted) ; Bradford v. Dir. Gen. of Railroads of Mexico, 278 S.W. 251 (Tex. Civ. App. 1925) (since railroad is operated by agency of government, suit is against the state itself); Mason v. Intercolonial Ry. of Canada, 197 Mass. 349, 83 N.E. 876 (1908) (suit is "virtually against the king of a foreign country").

On two occasions the State Department, with consequent acquiescence by the courts, has recognized and allowed the immunity of a Mexican corporation operating cxpropriated oil fields. Mexico v. Schmuck, 293 N.Y. 264, 56 N.E.2d 577 (1944), reaff'd 294 N.Y. 265, 62 N.E.2d 64 (1945); F.W. Stone Engineering Co. v. Petroleos Mexicanos, $352 \mathrm{~Pa} .12,42$ A.2d 57 (1945). Courts have not, as yet, extended immunity this far in the absence of a "suggestion" from the State Department.

23. It was undoubtedly because of this doctrine that plaintiff in Suhl v. $M / V$ Rossia and the Amtorg Trading Corp., supra note 10, joined Amtorg, alleging that the Soviet corporation had an interest in the Rossia "as owner, agent, or operator." Had there been any merit to the allegation, the action could probably have been continucd against Amtorg even though the libel of the Rossia was dismissed. However, it was subsequently dropped by plaintiff.

24. Bank of U.S. v. Planters' Bank of Georgia, 9 Wheat. 904, 907 (1824). This rationale has been adopted in cases such as United States v. Deutches Kalisyndikat Geselischaft, 31 F.2d 199 (S.D.N.Y. 1929) (French potash cartel), and Ulen v. Bank Gospodarstwa Krajowego, 261 App. Div. 1, 24 N.Y. S.2d 201 (2nd Dep't 1940) (Polish bank).

25. E.g., Coale v. Société Co-op Suisse des Charbons, 21 F.2d 180 (S.D.N.Y. 1921) (Swiss coal importing corporation).

26. Cf. Amtorg Trading Corp. v. United States, 71 F.2d 524 (C.C.P.A. 1934).

27. See note 4 supra. A few United States decisions seem to approach this doctrine. Hannes v. Kingdom of Roumania Monopolies Inst., 260 App. Div. 189, 20 N.Y. S.2d 825 (1st Dep't 1940) (corporation formed to "exploit certain monopolies, issuc bouds, and float loans"); cf. Briggs v. Light-Boats, 11 Allen 157 (Mass. 1865); E.t partc: In the Matter of the State of New York, 256 U.S. 503 (1921). 
standard for the domestic problem of municipal corporation liability. ${ }^{29}$ In an international context, such a criterion encounters the added complication that concepts of what constitutes a "governmental" function are different in various countries. ${ }^{29}$ A more precise method, though still involving problems of classification, would be to impose liability upon the state for damages resulting from any commercial activities in which it engages. ${ }^{30}$ By looking to the nature of the activity rather than to formalistic categories, this standard would, in effect, equate the status of governments, insofar as they engage in trade, with the ordinary business enterprise. ${ }^{31}$

While this change in policy would obviously be decried by socialist countries, several factors make it unlikely that they would resort to retaliatory action. Economic repercussions do not seem probable in view of the importance of trade with this country for the rest of the world. And many nations, Great Britain being the most significant exception, have already imposed similar limitations on the scope of immunity so that the proposed change would approximate their longstanding practice. ${ }^{32}$ Moreover, the United States permits its own government corporations and non-military vessels to be sued in federal courts. ${ }^{33}$

28. See 6 MicQuillen, Miunictpal Corporations $\$ 2798$ (2d ed, 1923). For example, courts cannot even agree on the question of whether operating public parlss is "governmental" or "proprietary." Id. $\$ 2850$.

29. See Friedmann, stspra note 3, at 128. For an example of how two countries may differ in classifying the same type of transaction, compare Kingdom of Roumania $v$. Guaranty Trust Co. of N.Y., 250 Fed. 341 (2d Cir. 191S) (purchase of military supplies declared a sovereign function) cinth Stato di Rumania c. Trutta, I Monitore dei Tribunali 288 (1926) (nature of contract to buy military supplies held "extraneous to the exercise of sovereignty"), translated in 26 Asr. J. INr'L L. Supp. 627-9 (1932).

30. This principle was first proposed in 1891 by the Institut de Droit International. Scott, Resolutions of the Institute of International Law 91-2 (1916). It is also embodied in Article 11 of a suggested Draft Conzention of the Competence of Courts in Regard to Foreign States, 26 AMr. J. INr'L L. Supp. 451, 597 ct seq. (1932), providing for liability of all types of government owned instrumentalities engaged in trade; and for commercial ships and their cargoes in The Brussels Convention of 1926, U.S. DEPT. of State Treaty Info. Buzl. No. 18 (March, 1931) 67, which has been ratified by a few European nations.

31. Increased liability, of course, emphasizes the intricate collateral problem of how judgments can be executed against a foreign sovereign. For possible solutions see Droft Convention of the Conpetence of Courts in Regard to Forcign States, 26 Ans. J. Int' L. Supr. 451, 689-725 (1932); Note, 31 CoL. L. REv. 660 (1931).

32. See note 4 supra.

33. E.g., The Suits in Admiralty Act of 1920, 41 SrAT. 525 (1920), 46 U.S.C. $\$ \$ 741-52$ (1946), provides for the liability of merchant vessels or tugheats owned or in the possession of the United States or any corporation whose stods it owns, if suit is brought in United States courts. Liability is similarly provided for any corporation which may be created under the Economic Cooperation Act of 1943, Pub. L. No. 472, 80th Cong., 2d Sess., $\$ 104$ (d) (April 3, 1948). Cf. The Federal Tort Claims Act, 60 Srat. 842-847, 28 U.S.C. $\$ \$ 921-946$ (1946) which allows suit against the United States for injuries resulting from both commercial and non-commercial activities, although claims arising in a foreign country are excepted. 
While the diplomatically desirable method of promulgating such a restrica tion would be an international convention, the trend towards government ownership in Europe makes widespread approval of increased liability improbable at this time. ${ }^{34}$ But neither legal nor diplomatic considerations preclude unilateral action by the United States. ${ }^{35}$ Courts might make clear that they adhere to their previous doctrines merely because compelled to accede to the State Department; and to the extent that these doctrines are the only explanation for our present policy, the State Department can repudiate them.

Nor does the possibility that present policy might be founded instead on political expediency change the conclusion that, in the interest of private rights, immunity should be limited. Compared with other diplomatic devices, such as control of ERP funds, power to manipulate the grant of immunity seems relatively unimportant. Moreover, in the past suits against corporations owned by foreign governments have been allowed with no adverse diplomatic results in spite of vigorous claims of immunity. ${ }^{36}$

To reformulate United States policy two techniques are available: the State Department could issue a forthright statement that future claims of immunity for commercial instrumentalities will not be "recognized and allowed," or Congress could enact legislation setting up a general standard which would preclude recognition of such claims. A declaration would be the most direct method of accomplishing the change. But, since a mere declaration is easily modified, it may not be sufficient in itself to curtail expedient decisions significantly. If diplomatic pressures were allowed to force an ad hoc grant of immunity to one nation despite the declaration, it would then be difficult to deny that privilege to any friendly nation. By its relative inflexibility, legislation would obviate this difficulty. And Congressional action should diminish the possibility that an international incident might arise from an unsuccessful claim by unequivocally forewarning foreign nations that attempts to exert diplomatic pressure in behalf of claims of immunity for state trading organizations will be unavailing.

Against a background of increasing governmental trading activities, the broad grant of immunity accorded by the United States seems unduly liberal. Whether by State Department action or by legislation, sovereign immunity should be restricted to permit private parties to recover from government owned commercial instrumentalities.

34. Several existing conventions contain provisions concerning the liability of states, but none of these is widely applied today. See note 30 supra, and the summary of earlier maritime conventions in REPORT of THE COMMITTEE OF EXPERTS FOR THE PROgressive Codification of International Iaw on the Legal Status of Governasent ShIPs Employed in Commerce, (League of Nations Publications V: Legal No. c. 52 M. 29) (1926).

35. The only requirement of international comity is that whenever the criteria of immunity are modified, foreign governments be notified "in a manner not to be misunderstood." The Exchange, 7 Cranch 116, 146 (1812).

36. Sec notes 24,25 supra. 